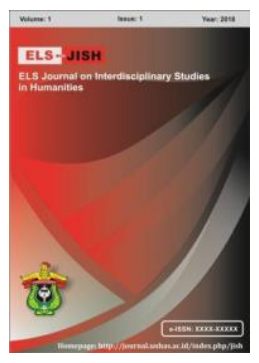

ELS-JISH

ELS Journal on Interdisciplinary Studies on Humanities

Volume 3 Issue 3, 2020

ISSN (print) : 2621-0843

ISSN (online) : 2621-0835

Homepage : http://journal.unhas.ac.id/index.php/jish

\title{
Analysis of Differences in the Use of Verb Synonyms in Indonesian Language
}

\author{
Raviqa $^{1}$ \\ 1raviqa92@gmail.com
}

\begin{abstract}
This study aims to analyze the differences in the use of verb synonyms in Indonesian language. Data are verbs and their synonym members, which are collected using observation and notetaking techniques. Data were analyzed using substitution and descriptive methods. The results showed that the distribution analysis provided two possible characteristics. The first possibility consisted of a number of verbs which have the possibility to distribute in parallel with all members of the synonym and the second possibility was the verbs that could not substitute one another (complementarily distributed) with all members of the synonym.
\end{abstract}

Keywords: Difference, Synonym, Verb

How to cite: Raviqa. (2020). Analysis of Differences in the Use of Verb Synonyms in Indonesian Language. ELS Journal on Interdisciplinary Studies in Humanities, 3(3), 476-491 DOI: https://doi.org/10.34050/elsjish.v3i3.11114

\section{Introduction}

Language as a means of communication for community members can be used to convey ideas to others so that whatever is stated can be understood and comprehended properly (Suherman, 2018). Conveying ideas to others is very dependent on the accuracy of choosing the word that represents it. In picking out words to represent the ideas, we are often faced with the problems of taking the words used correctly, such as the accuracy in selecting words that are synonymous in the context of the sentence. The accuracy in finding synonym words often does not match the meaning of the sentence to which it is attached. This happens because of ignorance or inaccuracy of language users in identifying words (Nazar, 2019).

Finding out the choice of words is closely related to the meaning of the word chosen or used in a context because it is the meaning that can express the ideas extended by the writer or speaker of that language (Aminuddin,1985; Keraf, 1988; Chaer, 2009; ). So, it can be identified that the accuracy of the meaning to be expressed really depends on the accuracy of determining the word. In accordance with the possibility that a synonymous word cannot replace each other in a sentence context, it is the rationale for the research title 
"Analysis of Differences in the Use of Verb Synonyms in Indonesian Language". In this research, we analyzed the discrimination of the use of verb synonyms or in other words the sharp differences in the use of verbs with their synonym members in the same or different contexts. In this research, we described the differences in the use of synonymous verbs in the same or different contexts without seeing any errors in the use of synonymous verbs in the research object. Verbs as the object of research were taken from an observation on the use of both written and spoken language that productively uses verbs. In its use, a number of verbs are found that have similar meanings with other verbs (synonymous). However, in the same context, these synonymous verbs cannot shift each other or they have different uses (Nazriani, 2020).

In accordance with the title to be discussed, this research will analyze a synonymous word. Based on this, it means that an investigation of vocabulary will be conducted and directly see the relationship between one word and another that is synonymous. Where are the differences and the coincidence of these words, and how are the relationships between one word and another synonymous word. In a sentence, a word is usually only representative of one meaning. It is different if the word stands alone and has nothing to do with a sentence. If a word stands alone and has nothing to do with a sentence, then the meaning of the word can be more than one, this can be seen in a dictionary. However, if a word is in a sentence, then the meaning, concept or event only refers to one meaning

Look at the sample data below.

Sejumlah saksi mata melihat sayap kanan pesawat lepas sebelum pesawat jatuh. (Kompas, 21-10-2013 page: 8) .

(A number of eyewitnesses saw the plane's right wing off before the plane crashed.)

The use of the word saw in the sentence above can be distributed with several synonyms based on the target aspects as follows

Sejumlah saksi mata $\left\{\begin{array}{c}\text { melihat: saw } \\ \text { menatap: stared } \\ \text { menonton: } \text { watched }\end{array}\right\}$ sayap kanan pesawat lepas sebelum pesawat jatuh.

The words, melihat (saw), menatap (stared), dan menonton (watched) are synonymous words when they stay alone. However, if the three words are attached to a sentence, it will emerge meanings that can be almost the same or even different. In the sentence above, some of these words cannot be exchanged with one another. In the above sentence, the word see can be exchanged with the word stare, but cannot be exchanged for the word watch. In the data presented above, it can be identified that the difference in meaning resulted from each word attached to the sentence. The word melihat in the sentence above means using the eye to look or pay attention (the right wing of the plane), then the word menatap means seeing an object in this case (the right wing of the plane), while the word menonton means seeing a show, a living image with a relaxed atmosphere. If the word menonton is used in the context of the sentence above, it seems incorrect. 
Based on the meaning of menonton (watch) in the sentence, the word menonton is considered unacceptable. The concordance of meaning is identified based on its target. The target is in the form of an object (right wing of the plane) while the use of the word menonton is only used for the target of a live show. Another factor causing differences in the use of the verb melihat (saw) with its synonym members is the prevalence of use (collocation limitations). The use of the word menonton (watch) in the above context is considered unusual. This is influenced by the atmosphere depicted in the above context. The word menonton is commonly used to describe an activity of seeing a show, a live image with a relaxed atmosphere, not a tense atmosphere as contained in the above context.

\section{Method}

\subsection{Data Collection}

Data collection was carried out through literature research and field research described as follow:

\subsubsection{Literature Research}

Literature research was applied to obtain secondary data, namely data that had been presented by previous people through books and the results of their research. In addition to obtaining secondary data, literature research is also intended to find scientific principles (theories related to the issues discussed).

\subsubsection{Field Research}

This field research was conducted to obtain primary data. In an effort to find and identify primary data, observations were made on the object under study that was all data obtained from various kinds of written languages. The data were gained through observation.

The observation method is one of the methods in research conducted by directly observing sentences that use verbs and their synonym members in the data source. The technique used in this method was note taking technique.

The note taking technique was a continuation of the observation method. The technique of recording was done by recording all data found through data sources. Data about sentences that use verbs and their synonyms were recorded on the data card. Furthermore, the data were classified based on the level of meaning similarity.

\subsection{Data Sources}

In relation to research on the analysis of differences in the use of synonymous verbs, data sources were needed. The data taken were all sentences that used synonymous verbs and their members which were gathered through a variety of written languages, for example mass media kompas.com and books. 


\subsection{Population and Samples}

The population in this study was all sentences using synonymous verbs in various written languages, such as kompas.com and motivational books with the title "The Secret to Success in Building ESQ". The total population was 235 data.

Furthermore, the sample was an example (in the form of a sentence) which was used as a reference. These samples were selected purposively, i.e. samples were selected based on the consideration that the sample was representative of the entire population of other data. The samples in this study were 70 data from all populations.

\subsection{Data Analysis Method}

Two methods were used to analyze primary data, namely the substitution method and the descriptive method

\subsubsection{Substitution Method}

The substitution method is a data analysis method used by distributing data alternately in the context. This substitution method consists of complementary and parallel substitution. This is intended to prove or see the degree of similarity and difference to the verbs and their synonym members analyzed.

\subsubsection{Descriptive Method}

Descriptive method is a data analysis method that describes data in scientific writing as it is. Data collection is in accordance with the facts obtained from the object of research. In this research, the descriptive method is used as a continuation of the substitution method.

\section{Findings and Discussion}

\subsection{Analysis of Differences in the Use of Verb Synonyms in Indonesian Language}

There are no synonymous words that are one hundred percent same, only more or less the same or almost the same meaning. Before entering into the discussion / analysis, first some verbs in Indonesian are identified and their synonym members. Then distribute synonym words consecutively based on their identification.

\subsection{Identification of Verb Synonyms}

Identification is "the determination and decision of identity (people, objects and so on)". The purpose of this identification is to easily know the relationship between the meanings of synonymous words and is intended so that discussions can be carried out in an order and systematic manner (Sari et al., 2019). The identification of synonyms for verbs in Indonesian is as follows. :

Data 1

Memegang (hold) 
Synonym:

$$
\begin{aligned}
& \text { menangkap (catch) } \\
& \text { menggenggam (grasp) } \\
& \text { mencengkeram (grip) } \\
& \text { meraba (grope) } \\
& \text { menyentuh (touch) } \\
& \text { menjamah (feel) } \\
& \text { menerkam (pounce) }
\end{aligned}
$$

Identification of a number of words that are synonymous with the word memegang (hold) above, in terms of usage in a context is difficult to distinguish. This is reasonable because between these verbs sometimes have different meanings from various aspects such as means, goals and situations (Kridalaksana, 1994 ;Alwi, et al. 2003).

Described in the Big Indonesian Dictionary (KBBI), the word memegang (hold) means loading by hand; holding (money, etc.); menangkap (catch) means to hold (something that moves quickly, releases, etc.); holding (animals, thieves, criminals, etc.) with hands or tools; menggenggam (grasp) means to hold in clenched fists; mencengkeram (grip) means using claws (nails, hands) to grip; to grasp; meraba (grope) means to touch (hold, touch) with the palms of the hands because they want to feel or look for something; menyentuh (touch) means to offend a little, feel; menjamah (feel) means touching with fingers; fingering; holding; menerkam (pounce) means to hit (jump) to grip (catch); hit.

Data 2

Mengambil (take)

Synonym: Group 1

memetik (pick)

memungut (pick up)

mencomot (pluck)

menjumput (graze)

Synonym: Group 2

mencuri (steal)

menyita (confiscate)

merampas (loot)

merebut (seize)

merenggut (snatch)

Identification of a number of words that are synonymous with the word mengambil (take) above, considering about terms of usage in a context is difficult to distinguish. This is reasonable because between these verbs, they sometimes have different meanings from various aspects such as means, goals and situations (Darwis, 2012).

Described in KBBI the word mengambil (take) means to hold something and then carry it (lift it, use it, keep it, etc.); memungut (pick up) means taking what's on the ground or on the floor (due to falls, etc.); mencomot (pluck) means to take (hold) or anchor with five fingers; menjumput (graze) means picking up (taking with two fingertips or the like); menyita (confiscate) means taking, 
seizing and holding goods, carried out by state apparatus (police etc.) in accordance with a judge's decision; merampas (loot) means to take by force (by force); merebut (seize); means to take something by force or by force; merenggut (snatch) means to pull (jerk, grab, pull) by force.

Data 3

Menulis (write)

Synonym:

mencatat (take note)

Menoreh (incise)

menyalin (copy)

mengarang (make up a story)

menggubah (compose)

melukis (paint)

menggambar (draw)

menyusun (compile)

Identifying a number of words that are synonymous with the word noted above, in terms of usage in a context is difficult to distinguish. This is reasonable because between these verbs sometimes have different meanings from various aspects such as tools, goals and situations.

As they are found in KBBI the word menulis (write) means making letters (numbers, etc.) with a pen (pencil, chalk, etc.), giving birth to thoughts or feelings (such as composing, writing letters) by writing, drawing; paint; mencatat (take notes) means to write something down for warning (in a notebook); menoreh (incise) means cutting not too deep on the bark, etc.; scratch; menyalin (copy) means quoting (writing); rewrite; Imitate; mengarang (make up a story) means writing and composing a story, book, poem, etc .; menggubah (compose) means creating story, song, etc.; melukis (paint) means making pictures using pencils, pens, brushes, etc., whether with color or not; menggambar (draw) means to draw a picture; paint; composing means composing a book (Untara, 2012).

\subsection{Differences in the Use of Verb Synonyms in Indonesian Language}

Based on the research method that has been written previously, data on verbs and their synonym members are analyzed based on the distributional method. Some verbs in Indonesian and their synonym members can be seen as similar and different through distribution alternately in the same context. The word / term distribution in this study is distribution based on paradigmatic understanding. In the previous section, it was written that the distribution based on the paradigmatic understanding is the possibility of replacing (substitution) of an element in a sentence / phrase with another element vertically (vertically). This is intended to determine which synonyms are distributed in parallel and which are complementary distributed. In this way, synonymous words can be distinguished (Soedjito, 1988: 7). 
Data 1

Memegang (hold)

1) Terus ibu Saragih datang dan marah, Bang," tutur Khairul (8), mewakili rekan-rekannya yang diam $\left\{\begin{array}{c}\text { memegang: holding } \\ \text { menangkap (catching) } \\ \text { menggenggam (grasping) } \\ \text { mencengkeram (gripping) } \\ \text { meraba (groping) } \\ \text { menyentuh (touching) } \\ \text { menjamah (feeling) }\end{array}\right\}$ kepala mereka masing- masing. (www.kompas.com, 25-02-142)

(Then Saragih's mother came and was angry," Brother, "said Khairul (8), representing his colleagues who were holding their heads silently each of them)

It can be observed from the data that the possibility of substitution between the word memegang (hold) and its synonym cannot be applied. The word memegang (hold) can only be distributed in parallel with the words mencengkeram (grip), meraba (grope), menyentuh (touch) and menjamah (feel). The word memegang (hold) means sticking with your hand. While mencengkeram (grasp) means holding tightly with the claws (nails); mieraba (grope) means touching (holding) with the palms of the hand because you want to feel or looking for something, menyentuh (touch) means to offend a little; feel something and menjamah (feel) means touching with fingers; holds up. The correspondence of these words with the object they are attached to makes these words considered acceptable in the above context.

Meanwhile, the words menangkap (catch) and menggenggam (grasp) cannot be substituted for word memegiang (hold) or have complementary distribution. This is due to the different aspects of meaning resulting from the words menangkap (catch) and menggenggam (grasp) in the above context. The word mencengkeram (grip) means to hold tightly with your claws (nails). Based on the meaning contained in the word menangkap (catch), it is to hold (something that moves quickly, releases, etc.); holding (animals, thieves, criminals, etc.) with hands or tools. The word menangkap (catch) is considered non-substitutable because this word is only intended for an object that is moving and is released not on objects that are attached to the body as in the sentence above, namely the head.

As for menggenggam (grasp) means holding with clenched fists. It is also not interchangeable because the use of the word menggenggam (grasp) means to hold in a clenched fist and the object that is being held is submerged or not visible because it is in the grasp. Meanwhile, if the word menggenggam (grasp) is used in the sentence above, it is not precisely. This is caused by an unusual 
object. The difference in the use of these synonymous words is caused by a fundamental difference in the aspects of the meaning contained, both the emotive meaning and the collocation meaning, so that it affects the prevalence of word use.

2) Mendapatkan bukti itu, polisi kemudian $\left\{\begin{array}{c}\text { menangkap (arrested) } \\ \text { memegang (held) } \\ \text { menggenggam (grasped) } \\ \text { mencengkeram (gripped) } \\ \text { meraba (groped) } \\ \text { menyentuh (touched) } \\ \text { menjamah (felt) }\end{array}\right\} 11$ orang termasuk pemilik restoran "ekstrem" itu. (www.kompas.com, 13-0214) (Obtaining the evidence, the police then arrested 11 people including the owner of the "extreme" restaurant.)

In sentence (2) above, the word menangkap (arrest) cannot automatically substitute with all its synonym members. The word menangkap (arrest) is only substituted in parallel with the word memegang (hold). The word menangkap (catch) is an additional meaning of the word memegang (hold). In the sentence above, the word menangkap (arrest) means to hold (animal, thief, criminals, etc.) with hands or tools. Furthermore, the word menangkap (arrest) has a complementary distribution with the words menggenggam (grasp), mencengkeram (grip), meraba (grope), menyentuh (touch), and menjamah (feel). This is due to the incompatibility of the meaning contained in these words with the above the context of .memegang (held)

3) Tangannya $\left\{\begin{array}{c}\text { mencengkeram: gripped } \\ \text { menggenggam (grasped } \\ \text { memegang (held) } \\ \text { meraba (groped) } \\ \text { menyentuh (touched) } \\ \text { menjamah (felt) } \\ \text { menangkap (caught) }\end{array}\right\}$ bahuku kencang.

(www.kompas.com, 21-01-14)

(His hands gripped my shoulders tightly)

In sentence (3) above, the word mencengkeram (grip) does not necessarily substitute for all its synonym members. The word mencengkeram (grip) can only distribute parallel to the word memegang (hold). This is because the word mencengkeram (grip) is an additional meaning of the word memegang (hold). Mencengkeram (grip) means holding tightly with your claws (nails). Memegang (hold) can be substituted by mencengkeram (grip) because the meaning of the word mencengkeram (grip) contains the meaning of memegang (hold). 
Furthermore, the words menangkap (catch), menggenggam (grasp), meraba (grope), menyentuh (touch), and menjamah (feel) have a complementary distribution with the word mencengkeram (grip). This is due to different aspects of the meaning contained in each word which in turn causes the unusual use of these words in the context above. The word menangkap (catch) means to hold (something that moves fast, releases, etc.); holding (animals, thieves, criminals, etc.) with hands or tools, while in the sentence above the object in question is the shoulder which is permanently in place (not moving).

Also, the word menggenggam (grasp) means holding with clenched fists. The word menggenggam (grasp) cannot be substituted for mencengkeram (grip) due to differences in method. Mencengkeram (grip) means using nails, while menggenggam (grasp) not using nails but with clenched fists.

In addition, meraba (grope) means touching (holding, touching) with the palms of the hands because you want to feel or look for something. The words also cannot replace each other with mencengkeram (grip) because of the different purpose of the two words. The word mencengkeram (grip) in the above sentence implies or aims to hold tight, while meraba (grope) contains the aspect of the goal to feel or look for something.

Then, the word menyentuh (touch) means to offend a little, and the word is not acceptable when used in the above context because of the use of the word "tightly". It has a clearly different collocation with the word menyentuh (touch). Finally menjamah (feel) means touching with fingers; fingering; holds up. Unlike the case with mencengkeram (grip) which means holding tightly with the claws, menjamah (feel) means holding with the fingers and not tightly. The difference in this aspect of the method causes the two for not clearly replace each other.

Data 2

Mengambil (take)

1) Ayah yang datang untuk $\left\{\begin{array}{c}\text { mengambil (to take) } \\ \text { memetik (to pick) } \\ \text { memungut (to pick up) } \\ \text { menjumput (to get a pinch of }) \\ \text { mencomot (to snatch) }\end{array}\right\}$ rapor sampai terbelalak. (www.kompas.com, 13-02-14)

(The father who came to take the report book was wide-eyed.)

By considering the distribution of the word mengambil (take) with its synonym in the sentence above, it appears that the possibility of a substitution between the word mengambil (take) and its synonym cannot be implemented automatically. The word mengambil (take) is complementary distributed with all its synonym members. The word mengambil (take) means holding something 
and then being carried (lifted, used, stored, etc.). In this case, the object taken is a report book. The word mengambil (take) cannot be substituted with the words memetik (pick), memungut (pick up), mencomot (snatch) and menjumput (get a pinch of) which are caused by differences in various aspects. Firstly, the word memetik (pic)k, which implies taking by breaking its stalk (flower, fruit, etc.). The unusual use of the word memetik (pick) is caused by differences in the target. The object is a report book while the word memetik (pick) is only commonly used to describe the activity of taking flowers, fruit, etc. The word memungut (pick up) means taking what is on the ground or on the floor (due to falling, etc.). The subject does the activity of taking (report book) which is not falling, but in a good situation.

Furthermore, the word menjumput (get a pinch of) means picking (taking a little at a time with two finger tips). There is a difference in terms of the method between the words mengambil (take) in general and this means that they cannot replace each other. The word mengambil (take) means to hold (book) to be carried and stored and retrieved by holding it with your hands, not using both fingertips. Then mencomot (snatch) means taking (holding) or hooking with five fingers. Even though, it is determined that mencomot (snatch) means taking using all five fingers, but there are differences in terms of method. In the word mencomot (snatch), the five fingers are functioned by linking an object to be collected. Meanwhile, in the context above, the report book is directly taken using the five fingers without having to be linked.

2) Hanya saja, $\left\{\begin{array}{c}\text { memetik (picking) } \\ \text { mengambil (taking) } \\ \text { memungut (picking up) } \\ \text { menjumput (getting a pinch of }) \\ \text { mencomot (snatching) }\end{array}\right\}$ buah yang berdebu dengan lahan tertutup pasir tebal tentu lebih sulit.(www.kompas.com, 1502-14)

(Merely, picking dusty fruit from land covered by thick sand is certainly more difficult.)

Based on the sentence above the word memetik (pick) can be distributed parallel with all its synonym members. This is due to the suitability of the relationship between the meanings of all these words and the object they get into. The object in the sentence above is fruit. The word memetik (pick) implies taking by breaking the stalk (flower, fruit, etc.). Although it contains aspects of the method (taken by breaking the stem (fruit), the word mengambil (take), memungut (pick up), mencomot (snatch), and menjumput (get a pinch of) can replace each other with the word mematahkan (break) due to the suitability of the meaning of the word with the sentence situation. 
Also, the "fruit" which is meant as an object contains a possibility is no longer fused with the stem but has fallen to the ground. This can be seen by reading the above sentence, so that some members of the synonym can loosely substitute the word memetik (pick). The work mengambil (take) can substitute with memetik (pick) because it is an additional meaning from the word mengambil (take).

Then, the word memungut (pick up) which in addition to the meaning of taking what is on the ground (due to falling, etc.) also means memetik (pick) (fruit, crop yields, etc.) The existence of a similarity or relationship between the meaning of memetik (pick) and memungut (pick up) in the above sentence causes both of them to replace each other. As for menjumput (get a pinch of), which means picking up (take with two fingertips or the like) is also considered acceptable in the above context.

Moreover, the "fruit" which becomes the object does not contain the meaning "still in or attached to the stem" so that it can be understood that the "fruit" in question has fallen to the ground and can eventually be picked up (taken or collected) with two fingers). Then mencomot (snatch) means to take (hold) or anchor with five fingers. It can also be substituted because it contains the same objective aspect, which is to collect "fruit".

3) Kall

ini,

peserta

perjalanan

bisa

$\left\{\begin{array}{c}\text { mencomot } \text { (snatch) } \\ \text { mengambil } \text { (taking) } \\ \text { memungut (pick up) } \\ \text { menjumput }(\text { get a pinch of }) \\ \text { memetik (pick) }\end{array}\right\}$ langsung nopia yang baru saja matang.

(www.kompas.com, 10-12-13)

(This time, the tour participants could directly snatch the just cooked Nopia.)

From the sentence, the word mencomot (snatch) does not necessarily replace each other with all its synonym members. It can only distribute in parallel with the words mengambil (take) and menjumput (get a pinch of). Mencomot (snatch) is an additional meaning of the word mengambil (take) which means holding something and then being carried (picked up, used, stored, etc.). In addition, the word mencomot (snatch) means taking (holding) or linking with the five fingers. Although it contains aspects of method (taken using five fingers), the word menjumput (get a pinch of) which means picking up (taking with two fingertips or the like) is considered acceptable in the above sentence. This is due to the suitability of the object being faced, namely in the form of nopia. Nopia is a type of snack that is relatively small, so it can be picked up (taken using two fingers). 
Meanwhile, the words memetik (pick) and memungut (pick up) have complementary distributions with the word mencomot (snatch) due to differences in several aspects. The word memetik (pick) implies taking by breaking the stalk (flower, fruit, etc.). In general, the word memetik (pick) is used on an object in the form of plants: a flower or a fruit. So, the word memetik (pick) is considered unacceptable because the object of the sentence above is cake (nopia). As for the word memungut (pick up), which means taking what is on the ground or floor (due to falling, etc.) it is also not commonly used in the above context. This irregularity was caused by different situations. The object clearly referred to in this case the cake (nopia) is not in a fallen state but is in a cake gutter.

Data 3

Menulis (write)

1) Saat saya $\left\{\begin{array}{c}\text { menulis (wrote) } \\ \text { mencatat (took note) } \\ \text { menoreh (incised) } \\ \text { menyalin (copied) } \\ \text { mengarang (made up a story) } \\ \text { menggubah (composed) } \\ \text { melukis (painted) } \\ \text { menggambar (drew) } \\ \text { menyusun (compiled) }\end{array}\right\}$ buku ini, dunia usaha

Indonesia sedang menghadapi badai dahsyat, tingkat insflasi tinggi, nilai rupiah tidak menentu, daya beli masyrakat merosot tajam, harga-harga menjulang tinggi dan tidak ada kepastian hukum. (RSM ESQ, Hal:112)

(As I write this book, the business world in Indonesia was facing a devastating storm, a high inflation rate, an uncertain rupiah value, the people's purchasing power had fallen sharply, prices were soaring and there was no legal certainty.)

In the sentence above, the word menulis (write) does not necessarily replace each other with all members of the synonym. The word menulis (write) can only distribute in parallel with the words menyusun (compile), mengarang (make up a story) and menggubah (compose). The word menulis (write) means expresses thoughts or feelings (such as make up a story, or creating letters) by writing, in this case in the form of a book. The word menulis (write) can be substituted with the word mengarang (make up a story) and menggubah (compose), this is due to the very close relationship of the meaning of the three words. Mengarang (make up a story) means writing and composing a story, book, poem, etc.

In addition to mengarang (make up a story), menggubah (compose) means to make up stories, poems, songs, etc. Then, the word menyusun 
(compile) means composing a book (dictionary, encyclopedia, etc.). The existence of this object equation causes the word menyusun (compile) to replace each other with the word menulis (write). The word menyusun (compile) is commonly used for an object in the form of non-fiction works such as books, not for works of fiction. The similarities in the meaning aspects contained in the three words make these words commonly used in the above context. Besides, the conformity with the intended object makes these words acceptable when substituted

As for the words mencatat (take notes), menoreh (incise), menyalin (copy), melukis (paint), and menggambar (draw), they have a complementary distribution with the word menulis (write). This is due to differences in several aspects of the meaning contained in each word. Mencatat (take notes) means writing something for a warning (in a notebook); write down what other people have written or said. Meanwhile, in the sentence above, it contains a process by thought and feeling in the form of a poetry creation. So the word mencatat (take notes) is considered unacceptable because in the above context, it does not mean rewriting what already existed but a creation. The word (incise) means to scratch. The word menoreh (incise) is more appropriate for writing activities (carving) a handicraft. So the word menoreh (incise) cannot substitute the word writing.

Furthermore, the word menyalin (copy) contains the meaning of quoting (writing); rewrite; Imitate. The meaning of the word menyalin (copy) has a close meaning with the word mencatat (take note), so that the word menyalin (copy) cannot be substituted in the above context. Finally, the words melukis (paint) and menggambar (draw) cannot replace each other. Melukis (paint) means making pictures using pencils, pens, brushes, etc., whether with color or not. While menggambar (draw) means making pictures; paint. After identifying the meaning of the two words, it is clearly found that these words cannot change the word menulis (write) in the above sentence.

2) Hasil penjelajahannya di Samarinda - Tenggarong - Banjarmasin dan menulis (wrote) mencatat (took note) menoreh (incised) pedalaman Kalimantan, Bock $\left\{\begin{array}{c}\text { menyalin (copied) } \\ \text { mengarang (made up a story) }\end{array}\right\}$ buku menggubah (composed) melukis (painted) menggambar (drew) menyusun (compiled)

berjudul The Head Hunters of Borneo yang terbit pada 1881, lengkap dengan 37 litografi dan ilustrasi. (www.kompas.com, 25 -25-14) 
(As a result of his exploration in Samarinda-Tenggarong-Banjarmasin and the interior of Kalimantan, Bock wrote a book entitled The Head Hunters of Borneo, published in 1881, complete with 37 lithography and illustrations.)

Considering the sentence above, the word menulis (write) does not necessarily relieve each other with all members of the synonym. The word menulis (write) can only have parallel distribution with the word mengarang (make up a story), menggubah (compose) and menyusun (compile). It is different from the previous sentence (1), in sentence (2), the word menyusun (compile) can be substituted with the word menulis (write). the word menulis (write) means expressing or creating thoughts or feelings by writing, in this case in the form of a book. Likewise, the meaning of the words mengarang (make up a story), menggubah (compose) and menyusun (compile) which means to write a book, whether a book in the form of a novel or dictionary, encyclopedia, etc.

As can be identified, the words mencatat (take note), menyalin (copy), menoreh (incise), melukis (paint), and menggambar (draw), they have complementary distribution with the word menulis (write). It has been explained in the previous first sentence that the words menyalin (copy) and mencatat (take note) have close meaning. The two words cannot substitute each other with the word menulis (write), because the above context contains an activity of creating, not simply moving or tracing existing writing. Furthermore, the words menoreh (incise), melukis (paint), and menggambar (draw) are also related to the art of writing to make works in the form of carvings or drawings using writing media such as pencils, pens, brushes, etc., whether with color or not. This difference in aspects causes the three words not to change each other with the word menulis (write).

3) Minggu pagi itu, setelah sempat lepas dari kanvas yang belum selesai digarapnya, Dwi Putro kembali tenggelam dalam "hening" $\left\{\begin{array}{c}\text { menggambar } \text { (drew) } \\ \text { mencatat (took note) } \\ \text { menoreh (incised) } \\ \text { menyalin (copied) } \\ \text { mengarang (made up a story) } \\ \text { menggubah (composed) } \\ \text { melukis (painted) } \\ \text { menulis (wrote) } \\ \text { menyusun (compiled) }\end{array}\right\}$ kijang emas yang memikat Shinta keluar dari perlindungan pagar magis Lesmana. (www.kompas.com, 28-04-13). (That Sunday morning, after taking off his unfinished canvas, Dwi Putro sank back into silence, drawing the golden deer that lured Shinta out of the protection of Lesmana's magical fence.) 
From the sentence above, the word menggambar (draw) cannot replace each other with several synonym members. The word menggambar (draw) can only have a parallel distribution with the word melukis (paint). This is due to the very close relationship between the meaning of two words, which means making a picture, in this case a picture of a golden deer. The similarities in terms of the results created and the similarities in the media make these two words interchangeable. It is different with the words menulis (write), mencatat (take note), menoreh (incise), menyalin (copy), mengarang (make up a story), menggubah (compose), dan menyusun (compile) which have a complementary distribution of word menggambar (draw). Menulis (write) means making letters (numbers, etc.) with a pen (pencil, chalk, etc.). Although there are similarities in terms of media that can be used in melukis (paint) and menggambar (draw) activities, in the above context the word menulis (write) is considered unacceptable. This is due to differences in the target or object being aimed, namely in the form of a golden deer. Likewise with the word mencatat (take note), menoreh (incise), menyalin (copy), mengarang (make up a story), menggubah (compose) and menyusun (compile).

The words mencatat (take note) and menyalin (copy) means writing down what someone else has written (rewritten) or said. Meanwhile, in the sentence above, the object in question is not graffiti or a statement that has been said by someone and then rewritten, but a golden deer to be drawn. Furthermore, the words mengarang (make up a story), menggubah (compose) and menyusun (compile) which have close relation which means writing and compiling a story, book, poem, etc. Again there are differences in terms of the object or target being aimed at. The last, menoreh (incise) is also considered unacceptable in the sentence above. This is due to different aspects of the meaning contained. The word menoreh (incise) means scratching which is commonly used in a context with scratching or writing media that is different from the image media used in the above context.

\section{Conclusion}

Based on the analysis of the distribution of verbs and their synonyms in Indonesian language, two possible characteristics were found. The first possible distribution is a number of verbs that have the possibility to distribute in parallel with all their synonymous members. The second possibility distribution cannot be mutually substituted (complementary distributed) with all its synonymous members. Both possibilities are still limited by usage rules or depending on the context of the sentence. This means that in certain contexts it can replace each other (substitute) with all members of the synonym because of a fundamental change in meaning. However, in other contexts, the opposite occurs, namely that it cannot substitute members of the synonym. This can be seen in the distribution analysis. 


\section{References}

Alwasilah, A. C. (1987). Linguistik Suatu Pengantar . Bandung: Angkasa.

Alwi, et al. (2003). Tata Bahasa Baku Bahasa Indonesia. Jakarta: Balai Pustaka.

Aminuddin. (1985). Semantik Pengatar Studi tentang Makna". Bandung : Sinar Baru Algesindo.

Chaer, A. (2009). Pengantar Semantik Bahasa Indonesia.Jakarta : Rineka Cipta.

Darwis, M. (2012). Morfologi Bahasa Indonesia Bidang Verba. Makassar: CV. Menara Intan.

Keraf, G. (1988). Diksi dan Gaya Bahasa. Jakarta: PT.Gramedia.

Kridalaksana, H. (1994). Kelas Kata dalam Bahasa Indonesia. Jakarta: PT. Gramedia Pustaka Utama.

Nurjalal. (1994). Penggunaan Kata Melihat dan Sinonimnya dalam Bahasa Indonesia . Unpublished Thesis at Hasanuddin University.

Sari, P., Palangngan, S. T., Mulyaningsih, E., Samritin, \& Rahman, F. (2019). Environmental expression using discourse analysis. IOP Conference Series: Earth and Environmental Science, 343(1). https://doi.org/10.1088/1755-1315/343/1/012149

Soedjito. (1989). Sinonim. Bandung : CV. Sinar Baru.

Untara, W. (2012). Tesaurus Bahasa Indonesia. Yogyakarta: Indonesia Tera.

Suherman, L. A. (2018). The Analysis of Metaphorical Domain on English "Stab Verb" in Corpora. ELS Journal on Interdisciplinary Studies in Humanities, 1(1), 52-58. https://doi.org/10.34050/els-ish.v111.4190

Nazriani, Arsad (2020) Kesalahan Penggunaan Bahasa Indonesia dalam Ruang Publik (Media Luar Ruang) di Kota Baubau

Nazar, A. (2019). Reduplikasi Bahasa Ciacia di Desa Warinta Kecamatan Pasarwajo Kabupaten Buton. Sang Pencerah: Jurnal IImiah Universitas Muhammadiyah Buton, 3(1), 16-22. https://doi.org/10.35326/pencerah.v3i1.259 